M. Korchemlyuk ${ }^{1}$, Cand. Sc. (Tech.), orcid.org/0000-0003-3417-2962, L. Arkhipova ${ }^{2}$, Dr. Sc. (Tech.), Prof., orcid.org/0000-0002-8725-6943,

R. L. Kravchynskyi ${ }^{1}$, Cand. Sc. (Geogr.), orcid.org/0000-0003-3769-3106, J. D. Mykhailyuk ${ }^{2}$, Cand. Sc. (Tech.), orcid.org/0000-0003-2448-3847
1 - Carpathian National Nature Park, Yaremche, IvanoFrankivsk region, Ukraine, e-mail: martakor@yahoo.com; kravchinski@ukr.net

2 - Ivano-Frankivsk National Technical University of Oil and Gas, Ivano-Frankivsk, Ukraine, e-mail: konsevich@ukr.net; julja-mihayyljuk@rambler.ru

\title{
ANTHROPOGENIC INFLUENCE FROM POINT AND DIFFUSE SOURCES OF POLLUTION IN THE UPPER PRUT RIVER BASIN
}

Purpose. To perform a quantitative and qualitative impact assessment from point and diffuse sources of anthropogenic pollution on the Prut River basin within Ukraine.

Methodology. Based on the developed statistical information and the use of the Guidance Paper on Impact Analysis and Risk Assessment in accordance with the EU Water Directive (EU project "Environmental protection of international river basins"), load calculations have been carried out on four factors influencing the Prut ecosystem, namely, volumes of discharges of untreated sewage, the total share of sewage in the river, from agriculture and livestock production.

Findings. The main anthropogenic loads on the Prut river basin within Ivano-Frankivsk and Chernivtsi regions of Ukraine from point and diffuse sources have been analyzed and calculated. In fact, it has been confirmed that diffuse sources are the main pollutants of the Prut ecosystem. Non-canalized area caused the emission of organic and nutrient compounds into the river basin. According to the calculation of the indicators of diffuse load, water massifs in Kitsman, Kolomyia and Snyatyn districts are "possibly at risk" from agriculture, and in Hertzayivsky district - from livestock. The largest point polluters in the Prut River are communal enterprises of the settlements in Kolomyia and Chernivtsi.

Originality. The methodology for estimating loads on the river basin has been further developed by calculating load indicators, which allows the development and implementation of effective methods and tools for controlling the ecological safety of aquatic ecosystems.

Practical value. The results obtained are the basis for adapting European approaches to integrated water resources management and developing measures to minimize the risks from human activities in the Prut basin. The work has been implemented at the national level in the process of drafting the Prut River Basin Management Plan in the framework of the international project "Environmental protection of international river basins" (EPIRB) and improvement of the water monitoring system in the Carpathian National Nature Park.

Keywords: ecological safety, point and diffuse sources of pollution, stress indicators

Introduction. The expression "sustainable use of water resources" had being filled with new content for more than 20 years. Solving management problems, optimizing water use and water consumption on the basis of ecological safety and rational use of water resources, restoring the potential of aquatic ecosystems, taking into account significant man-made load and global climate change, are particularly relevant [1]. Currently national water management begins to consolidate the principles of integrated water resources management in the legislative sphere only. Meanwhile, man-made loads on aquatic ecosystems, including the Prut River, deteriorate their quality and create threats for the public health and hydrobionts [2].

Analysis of the recent research. Problems of ecological safety of hydroecosystems are widely presented in the works of national and foreign authors: B. R. Allenby, O. S. Voloshkina, T. E. Gridel, A. L. Revzon, G. I. Rudko, R.Williams, E.J.Henley, M.A.Shakhranyan, A. K. Shreiber, Y. O. Yakovlev and others. However, in

(c) Korchemlyuk M., Arkhipova L., Kravchynskyi R. L., Mykhailyuk J. D., 2019 the problem of ecological safety of specific hydroecosystems, in particular the Prut River, there remains a lot of uncertainties, such as the absence of a unified database of indicators of the state of the system, the imperfection of the monitoring system, the lack of experience in implementing the methodology of estimating anthropogenic load in accordance with the requirements of the European Union Water Framework Directive (EU WFD), and others. [3]. An important task is to carry out an analysis of loads and impacts on the Prut basin, which will identify the problem areas of the river (water bodies) that are at risk or possibly at risk of failing to achieve the environmental objectives of the EU WFD, namely a good ecological status or potential.

The objective of this article is further development of the methodology for identifying and assessing the environmental pressure from sources of human anthropogenic pollution in accordance with the requirements of the EU WFD and its practical testing within the Ukrainian part of the Prut river basin to implement the integrated water management plan for the transboundary basin.

Presentation of the main research. According to the analysis of statistical data, more than 200 industrial en- 
terprises of different capacities work in the Prut basin. It should be noted that most of them are so-called "secondary" water users, since their waste water is transported and treated at municipal waste water treatment plants [4]. The latter ones are significant point sources of a wide range of contamination, including organic, nutrient (nitrogen and phosphorus compounds) and various chemical pollutants. At the same time, most industrial enterprises dispose of their waste water without sufficient or without any treatment to the city sewage systems, among them - the enterprises of settlements of Vyzhnytsia, Hertsa, Putyla. In order to assess the anthropogenic loading from untreated waste water, which is associated with environmental emissions of organic compounds (Biochemical Oxygen Demand $\left(\mathrm{BOD}_{5}\right)$, Chemical Oxygen Demand (COD) and biogenes (total Nitrogen (Ntot) and total Phosphorus (Ptot)), an inventory of treatment facilities in agglomerations (settlements) with a population of 5,000 people in the Prut basin was conducted in accordance with the "Guidelines for the Analysis of Load/Influence (Risk Assessment) addressing hydromorphology and physic-chemistry in the Prut Basin" [5]. Let us note that the coverage level of the urban population by sewerage systems in the Prut basin is from 30 to $80 \%$.

On the basis of the developed statistical information and the Guidance Paper above-mentioned, a methodology for estimating pressure on the Prut River basin has been improved.

The following values for the population equivalent $(P E)$ (one person using the central sewage system) were used to calculate the emissions of $\mathrm{BOD}_{5}, \mathrm{COD}$, Ntot and Ptot in different settlements in the Prut basin, and the following emission results were obtained accordingly for $\mathrm{BOD}_{5}-60 \mathrm{~g} / \mathrm{day}$, for COD $-110 \mathrm{~g} / \mathrm{day}$, for Ntot $-8.8 \mathrm{~g} / \mathrm{day}$, for Ptot $=2.5 \mathrm{~g} /$ day, taking into account the considerable pressure from detergents with a high content of phosphates [6], with an additional coefficient of purification efficiency of 0.2 , based on practical knowledge and state standards, that the classical secondary treatment used in Ukrainian treatment plants reduces loading of waste water only by $20 \%$ of loads on phosphorus. Generation of pollutants by population increases in line with an increase in population [7].

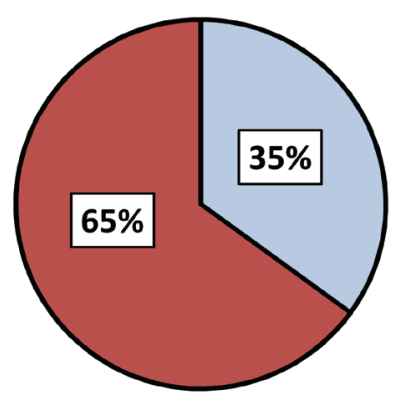

$a$

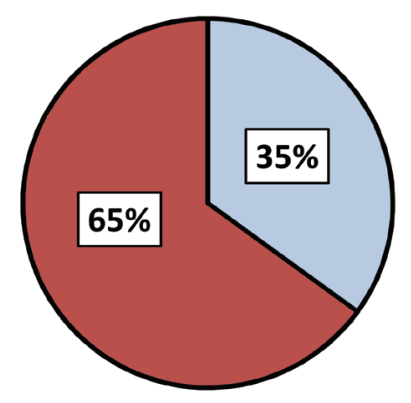

$b$

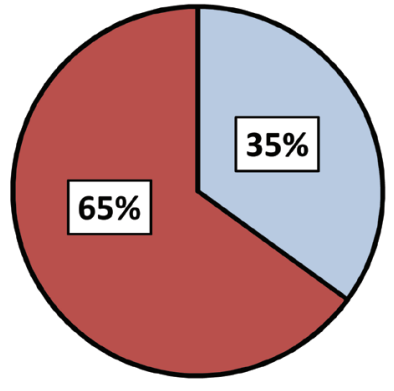

$c$

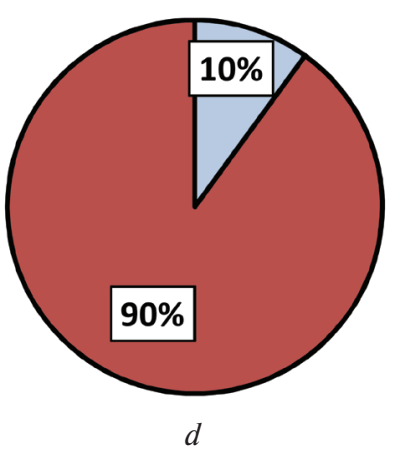

Fig. 1. The ratio of quality indicators of household waste water entering the Prut River within Yaremche town from the treated and untreated waste water:

$a$ - Biochemical Oxygen Consumption for 5 days $\left(B O D_{5}\right) ; b-$ Chemical Oxygen Consumption (COD); $c$ - Total Nitrogen (Ntot); $d-$ Total Phosphorus (Ptot) 
2) $1<D w w<1.5-$ ecological risk is possible;

3) $D w w<1-$ ecological risk is conditionally absent (minimal).

The results of calculating Indicator 1 for the research area are presented in Fig. 2.

On the basis of the obtained results, we conclude that the river water bodies in Kolomyia and Chernivtsi, below the sewage disposal sites, are identified as being "at risk", in Yaremche - as having "ecological risk conditionally absent", since there is no precise data on tourists in the town where the houses are connected to the centralized sewage system. However, according to official data of the Carpathian National Nature Park on the territory of Yaremche town there were officially registered 6078 visitors in 2012, 11275 - in 2013, $16363-$ in 2014 and 15666 - in 2015.

That is, in comparison with 2012, the number of visitors has increased by more than 2.5 times. And this means that emissions of pollutants are also increasing.

The tourist sphere creates an additional load on the water resources of the region. The natural features of Yaremche town and its suburbs create favorable conditions for the development of tourism throughout the year. There are 47 hotels (2292 places), 48 recreational establishments (2472 places), 552 green tourism households within the territory of Yaremche district. However, there is no information on the availability of permits for special water use, the volume of discharges of household sewage, and the way of their purification, as well as information on reporting on the form of "2TP-Vodhosp" in local administration bodies.

According to the National Report on the Quality of Drinking Water, Water Supply and Drainage, Fig. 3 shows the level of provision of these services by tourist destinations in Ivano-Frankivsk and Chernivtsi regions [9].

In the future we should expect an increase in the volume of household drinking and communal water use because of the connection of local water supply systems of rural settlements to the nearest city water supply and sewage systems.

The analysis of existing loads and influences allowed highlighting one of the key environmental problems (risks) for tourist destinations of the Carpathian region of contamination of water bodies (especially during periods of time) as point (discharges of untreated or insufficiently treated industrial and domestic waste water), and diffuse sources (untreated landfills of solid wastes, illegal dumps, livestock, agricultural wastes, individual septic tanks, illegal building in coastal protective strips, etc.), which leads to deterioration of the quality of drinking water supply sources.

Indicator II - the total share of sewage in the river. The indicator was calculated for 53 pollutants located in the Prut basin and the risk was assessed. The initial data is taken from the environmental passports of IvanoFrankivsk and Chernivtsi regions [7, 8]. According to the results of calculations, all river water bodies, in which household wastewater was discharged from 53 point sources were assessed as water bodies not being at risk.

The indicator of the total share of waste water in the river was calculated according to the following equation: $S w w=\sum Q w w / M Q r$

Description of used variables:

$S w w$ : total share of wastewater in a river at a given cross section along the river;

$Q w w$ : total of all (current/future) upstream wastewater discharges into the river $\left[\mathrm{m}^{3} / \mathrm{s}\right]$;

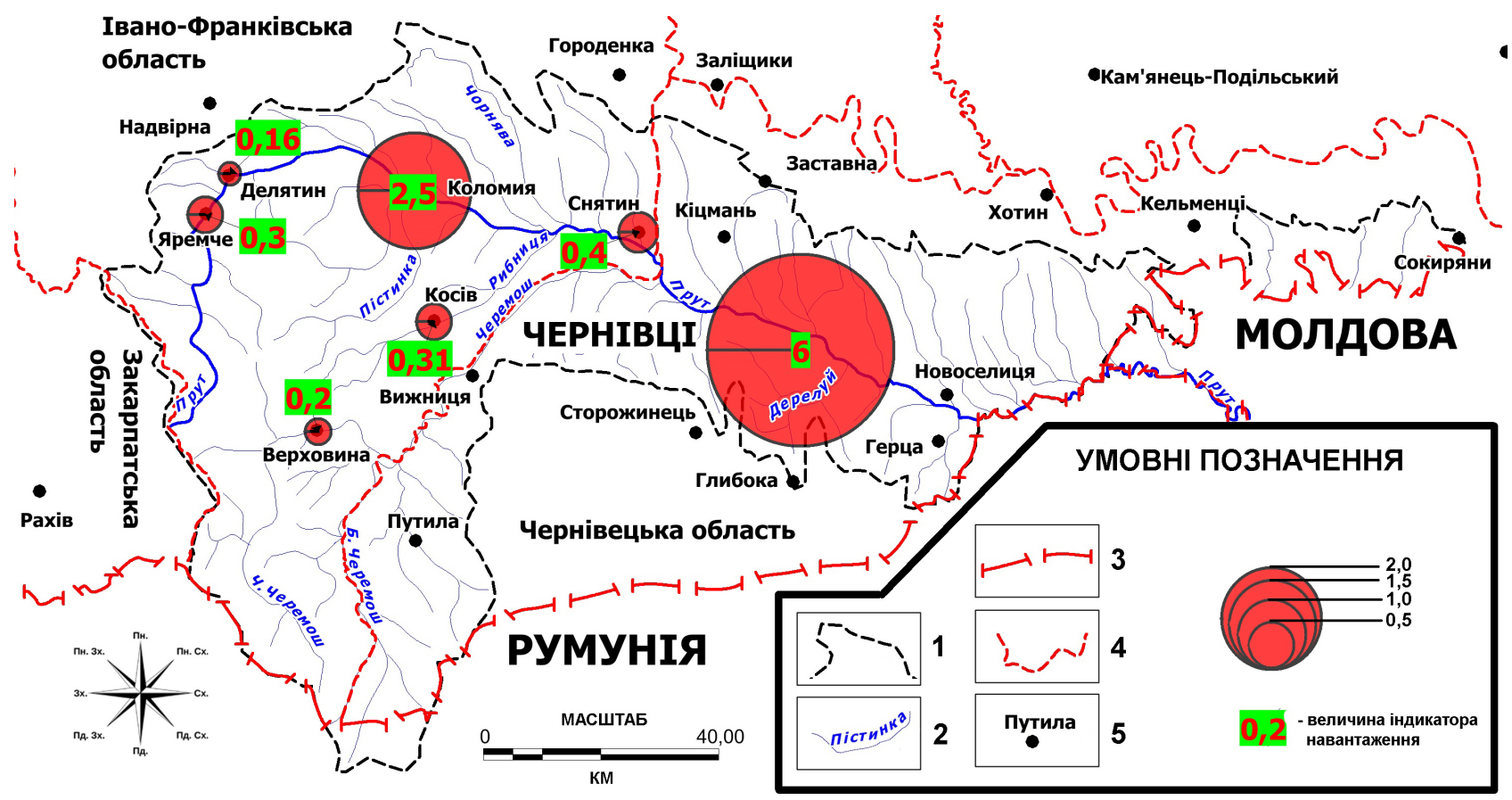

Fig. 2. Pressure Indicator of untreated waste water from point sources of pollution and risk assessment:

1 - the boundaries of the catchment area of the Ukraine part of the Prut River; 2 - the river and its name; 3 - the state border; 4 - the boundaries of administrative areas; 5 - settlements 


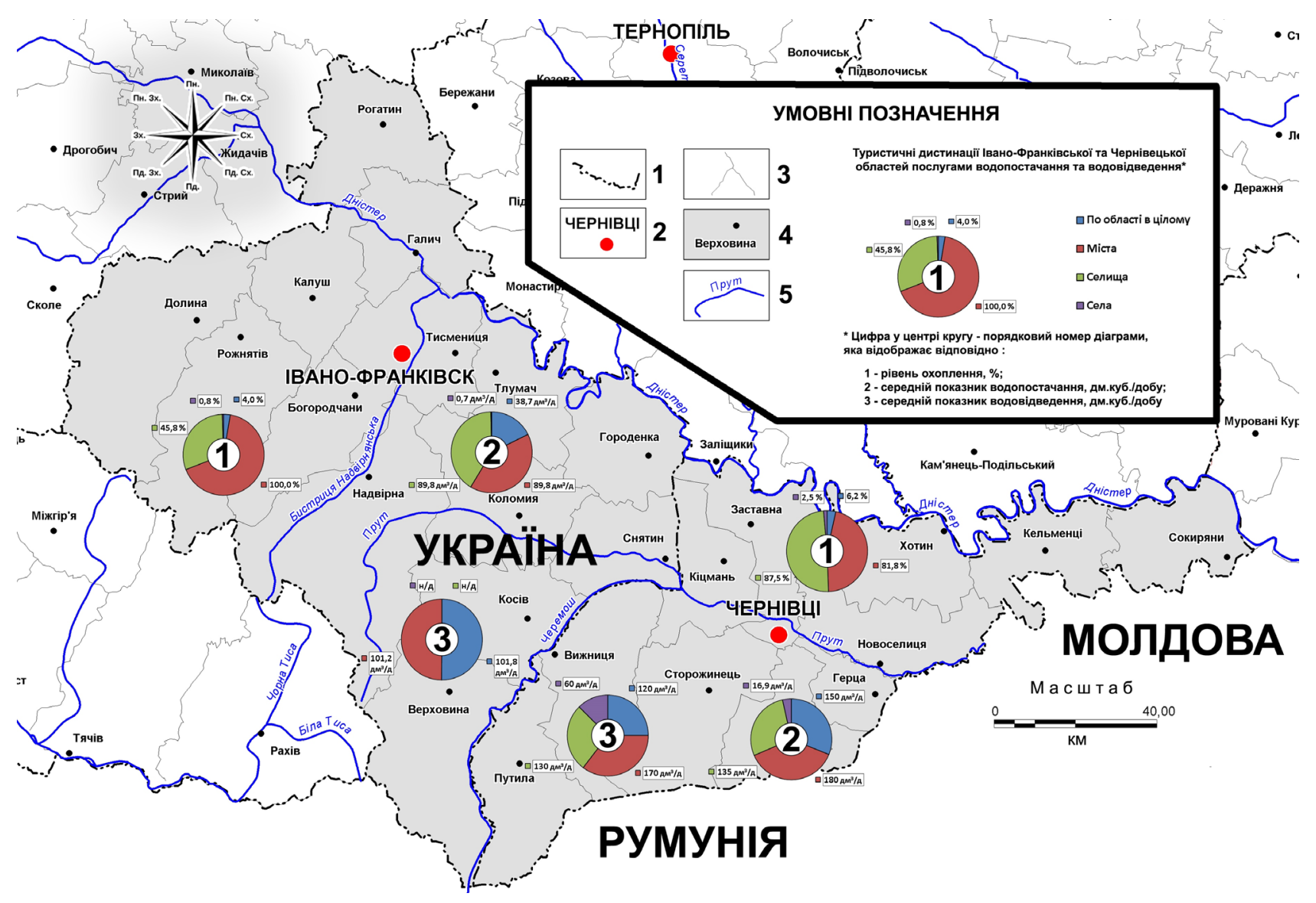

Fig. 3. Providing tourist services to Ivano-Frankivsk and Chernivtsi regions for water supply and sewage services:

1 - the boundaries of administrative areas; 2 - the regional administrative center and its name; 3 - boundaries of administrative districts; 4 - district center and its name; 5 - the river and its name

MQr: mean annual flow of the river $\left[\mathrm{m}^{3} / \mathrm{s}\right]$.

To assess risk, it is suggested that the authors use the following scoring scale:

$S w w>0.1-$ ecological risk is available;

$0.05<S w w<0.1-$ ecological risk is possible;

$S w w<0.05-$ ecological risk is conditionally absent (minimal).

Estimation of risk from contamination of the Prut River basin by diffuse sources. Anthropogenic loading from diffuse sources of pollution of surface and groundwater is due to the following reasons: lack of water protection zones; unregulated placement of solid household wastes, especially in rural areas; storage of mineral fertilizers; diffuse pollution from transport (emission of pollutants into the atmosphere, surface runoff from highways); agriculture (use of pesticides, surface runoff from livestock farms). A significant number of agglomerations from less than 10,000 inhabitants (small towns and villages) located in the Ukrainian part of the Prut River basin are provided with decentralized sanitation systems (septic tanks and cesspools), which are diffuse sources of pollution of local water bodies with organic, nutrient substances and lead to deterioration of the quality of water by microbiological indicators. One of the most significant diffuse sources of contamination with biogenes and microbiological contamination are settlements without proper sewage system treatment fa- cilities. According to the official data, the level of household connection to the sewerage system in the villages of Ivano-Frankivsk and Chernivtsi regions is extremely low.

In settlements without sewage or partial sewage systems, household wastewater is accumulated in decentralized sanitary systems: in septic tanks or cesspools. Annually, a significant proportion of untreated waste water, which is formed in the basin, leads to nitrate and microbial contamination of individual drinking wells and surface water bodies. Current data on the number of decentralized sewage systems in the Prut basin is absent. However, such systems are a significant component of anthropogenic load.

The next stage of our study was calculation of two indicators of agricultural load to assess the risks from the main factors of diffuse water pollution: growing of cultivated plants and livestock. The first indicator describes the probability of diffuse pollution from agricultural activities, in particular, from the use of fertilizers, pesticides and other plant protection products. The indicator uses common variables for the quantitative representation of agricultural activities.

In Ukraine, information on agricultural land is presented only in accordance with the administrative-territorial units that are not connected with the catchment area of the river basins. The smallest statistical unit is the 
district. The indicator was calculated for a portion of the river basin, which is completely in line with the territory of the district. This means that such a part of the river with all water bodies has the same impact of diffuse source of pollution.

The diffuse pollution indicator (Sagri) was calculated by the formula: Sagri $=$ Aagri/AWB, where Aagri is the area of agricultural land in the catchment, $\mathrm{km}^{2}$; $A W B$ is a catchment area, $\mathrm{km}^{2}$.

The following scale was used to assess the risk:

Sagri $>0.3$ - ecological risk is available;

$0.1<$ Sagri $<0.3-$ ecological risk is possible;

Sagri $<0.1-$ ecological risk is conditionally absent (minimal).

According to this criterion, the water bodies of the Prut river basin within the limits of the districts of Kitsman, Kolomyia and Sniatyn are at risk.

The second indicator describes the probability of diffuse contamination from typical pollutants coming from the surface runoff from livestock farms, namely biogenic substances with potentially toxic (e.g, $\left.\mathrm{NH}_{4}\right)$ or chronic effects (e.g. $\mathrm{PO}_{4}$ ) that change the biological quality elements and organic substances from a potential negative effect on the oxygen regime of the water.

The diffuse load indicator (Ihus) from livestock was calculated by the formula: Ihus $=U e / A w b$, where $U e$ is the total average arithmetic index [10] (for each animal species: cattle, goats, pigs, poultry, horses, sheep) multiplied by the number of individuals.

$$
\begin{gathered}
U e=(U e \text { cattle }+U e \text { sheep }+U e \text { pigs }+U e \text { poultry }+ \\
+U e \text { horses }+U e \text { goats }) / 6
\end{gathered}
$$
[10]:

Below is the numerical value of $U e$ for each animal

Ue for cattle -0.7

Ue for sheep -0.07 ;

$U e$ for pigs -0.3 ;

Ue for poultry -0.01 ;

Ue for horses -0.8 ;

Ue for goats -0.1 .

The scale was used to assess the risks:

Ihus $>1.0-$ a water body at risk;

$0.3<$ Ihus $<1.0-$ possibly at risk;

$0<$ Ihus $<0.3-$ not at risk.

The initial data on the number of livestock in the Prut basin was derived from statistical data for IvanoFrankivsk and Chernivtsi regions [7, 8]. Water bodies within the Hertsai district of the Chernivtsi region are "at risk", for others the risk from the probable diffuse contamination (from livestock) is minimal. The data from Ivano-Frankivsk region is not sufficient to assess the risks of diffuse contamination associated with livestock production.

Conclusions. The methodological foundations of balanced development of hydro ecosystems have been further developed. These are multicomponent dynamic systems that are under the influence of human engineering and economic activity and to a certain extent determine this activity [11]. In particular, the methodology for estimating loads on the river basin has been further developed by using a method for identification and assessment of sources of human anthropogenic pollution in accordance with the requirements of the EU Water Framework Directive, calculation of load indicators, which allows the development and implementation of effective methods and tools for controlling the environmental safety of hydroecosystems. For the first time, based on official statistical information, the main factors of loads and influences on the Prut ecosystem are substantiated by calculating environmental risk indicators from waste water, agriculture and livestock.

The main pollutants of the Prut River ecosystem are diffuse sources. Lack of a centralized drainage system causes the emission of organic and nutrient compounds to the water bodies. According to the results of calculating the diffuse load indicators, the water bodies in the Kitsmanskyi, Kolomyiskyi and Sniatynskyi districts, where widespread development of cultivation of crops has taken place, are possibly at risk. In Hertsayivskyi district, which is connected with the functioning of the livestock industry, water bodies are possibly at risk, too. The largest point sources of polluters in the Prut River basin are communal enterprises of Kolomyia and Chernivtsi settlements.

The obtained results are the basis for adaptation of European approaches to balanced development of hydro ecosystems, integrated water resources management and development of measures to minimize risks from human activities in the Prut River basin. The studies were tested in the framework of the EU project "Environmental Protection of International River Basins" (EPIRB).

\section{References.}

1. Adamenko, Y.O., Arkhypova, L. M. and Mandryk, O. M., 2017. Territorial Normative of Quality of Hydroecosystems of Protected Territories. Hydrobiological Journal, 53(2), pp. 50-58. DOI: 10.1615/HydrobJ. v53.i2.50.

2. Korchemlyuk, M. and Arkhypova, L., 2016. Environmental audit of Ukrainian basin ecosystem of the Prut river. Naukovyi Visnyk Natsionalnoho Hirnychoho Universytetu, 5(155), pp. 98-106.

3. Hryniuk, V. I. and Arkhypova, L. M., 2018. Regularity of effects of climatic changes on quality indicators of surface water of the Dniester basin. Naukovyi Visnyk Natsionalnoho Hirnychoho Universytetu, 3(165), pp. 125-133. DOI: 10.29202 /nvngu /2018-3 /17.

4. UNENGO "MAMA-86", 2014. A Pressure-Impact Analysis/Risk Assessment according to EUWFD, Part 2. / UNENGO "MAMA-86". Kyiv.

5. Vogel, B., 2014. Guidance Document addressing hydromorphology and physico-chemistry for a Pressure-Impact Analysis / Risk Assessment according to the EU WFD.

6. Technical Report: ICPDR Municipal Emission Inventory (2006/2007) [pdf]. Available at: <http://www. rowater.ro/TEST/Planul\%20de\%20Management $\% 20$ al\%20Districtului\%20International\%20al\%20Dunarii\%20\%202009/Anexe/DRBMP_Annex_03_Technical_Report_ICPDR_Municipal_Ēmission_Inventory. pdf $>$ [Accessed 15 November 2017]. 
7. Drona, V.S., ed., 2013. Statistical collection ["Environment of the Chernivtsi region in 2012"] [online]. Available at: <http://www.cv.ukrstat.gov.ua/publiy/eco/zb/ ZB_13.pdf> [Accessed 5 December 2017].

8. Ecological passport of Ivano-Frankivsk region for 2015 [online]. Available at: <http://www.menr.gov.ua/protection/protection1/ivanofrankivska $>$ [Accessed 12 November 2017].

9. Ministry of Regional Development, Construction and Housing and Communal Services of Ukraine, 2012. National report on drinking water quality and drinking water supply in Ukraine in 2011. Kyiv: Ministry of Regional Development, Construction and Housing and Communal Services of Ukraine.

10. Department for Environment, Food and Rural Affairs, 2003. Livestock units and stocking rates [online]. Available at: <http://adlib.everysite.co.uk/adlib/defra/ content.aspx?id=000IL3890W.198AWLDOHJ69F3> [Accessed 20 September 2017].

11. Mandryk, O.M., Arkhypova, L.M., Pukish, A.V., Zelmanovych, A. and Yakovlyuk, Kh., 2016. Theoretical and methodological foundations of sustainable development of Geosystems IOP Publishing. In: IOP Conference Series: Materials Science and Engineering. International Conference on Innovative Ideas in Science, (IIS2016) 10-11 November, Baia Mare, Romania. International databases Web of science, volume 200(2017) 012018 [online]. DOI: 10.1088/1757-899X/200/1/ 012018 .

\section{Антропогенний вплив від точкових і дифузних джерел забруднення в басейні Верхнього Пруту}

\author{
М. В. Корчемлюк ${ }^{1}$, Л. М. Архипова ${ }^{2}$, \\ Р. Л. Кравчинський ${ }^{1}$, Ю. Д. Михайлюк
}

1 - Карпатський національний природний парк, м. Яремче, Івано-Франківська область, Україна, е-mail: martakor@yahoo.com; kravchinski@ukr.net

2 - Івано-Франківський національний технічний університет нафти і газу, м. Івано-Франківськ, Україна, е-таil: konsevich@ukr.net; julja-mihayyljuk@rambler.ru

Мета. Виконати кількісно-якісну оцінку впливів точкових і дифузних джерел антропогенного забруднення на басейн Прута в межах України.

Методика. На основі опрацьованої статистичної інформації й використання керівного документу щодо аналізу впливів і оцінювання ризиків відповідно до Водної Рамкової Директиви ЄС (проект ЄC „Охорона навколишнього середовища міжнародних річкових басейнів“) проведені розрахунки індексів навантаження від чотирьох факторів впливу на Прутську екосистему, а саме: від об'ємів скидів неочищених стічних вод, загальної частки стічних вод у річці, від сільського господарства та тваринництва.

Результати. Проаналізовані та оцінені основні антропогенні навантаження на басейн ріки Прут у межах Івано-Франківської та Чернівецької областей України від точкових і дифузних джерел. Фак- тично підтверджено, що основними забруднювачами Прутської екосистеми є дифузні джерела. Неканалізована місцевість $є$ причиною емісію органічних і біогенних сполук до річкового басейну. За результатами розрахунку індикаторів дифузного навантаження „можливо під ризиком“ $є$ водні масиви у Кіцманському, Коломийському та Снятинському районах від сільського господарства, а в Герцаївському - через тваринництво. Найбільшими точковими забруднювачами р. Прут є комунальні підприємства населених пунктів Коломия та Чернівці.

Наукова новизна. Набула подальшого розвитку методологія оцінювання навантажень на річковий басейн шляхом індикаторів навантаження, що дозволяє розробляти та впроваджувати ефективні методи й засоби керування екологічною безпекою водних екосистем.

Практична значимість. Отримані результати є основою для адаптації європейських підходів до інтегрованого управління водними ресурсами й розробки заходів з мінімізації ризиків від антропогенної діяльності в басейні Пруту. Робота знайшла практичне впровадження на національному рівні у процесі розроблення проекту Плану управління річковим басейном Пруту в рамках міжнародного проекту $\mathrm{EC} \mathrm{„Охорона} \mathrm{довкілля} \mathrm{міжнародних} \mathrm{річ-}$ кових басейнів" (EPIRB) та вдосконаленні системи моніторингових досліджень вод на території Карпатського національного природного парку.

Ключові слова: екологічна безпека, точкові та дифузні джерела забруднення, індикатори навантаження

\section{Антропогенное воздействие от точечных и диффузных источников загрязнения
в бассейне Верхнего Прута}

М. В. Корчемлюк ${ }^{1}$, Л.Н. Архипова ${ }^{2}$, Р. Л. Кравчинский ${ }^{1}$, Ю. Д. Михайлюк

1 - Карпатский национальный природный парк, г. Яремче, Ивано-Франковская область, Украина, e-mail: martakor@yahoo.com; kravchinski@ukr.net

2 - Ивано-Франковский национальный технический университет нефти и газа, г. Ивано-Франковск, Украина, e-mail: konsevich@ukr.net; julja-mihayyljuk@rambler.ru

Цель. Выполнить количественно-качественную оценку воздействий точечных и диффузных источников антропогенного загрязнения на бассейн Прута в пределах Украины.

Методика. На основе разработанной статистической информации и использования руководящего документа по анализу воздействий и оценки рисков в соответствии с Водной Рамочной Директивой ЕС (проект ЕС „Охрана окружающей среды международных речных бассейнов“) проведены расчеты индексов нагрузки от четырех факторов влияния на Прутскую экосистему, а именно, от объемов сбросов неочищенных сточных вод, общей доли сточных вод в реке, от сельского хозяйства и животноводства. 
Результаты. Проанализированы и рассчитаны основные антропогенные нагрузки на бассейн реки Прут в пределах Ивано-Франковской и Черновицкой областей Украины от точечных и диффузных источников. Фактически подтверждено, что основными загрязнителями Прутской экосистемы является диффузные источники. Неканализированная местность является причиной эмиссии органических и биогенных соединений в речной бассейн. По результатам расчета индикаторов диффузной нагрузки „возможно под риском“ являются водные массивы в Кицманском, Коломыйском и Снятинском районах от сельского хозяйства, а в Герцаевском - от животноводства. Крупнейшими точечными загрязнителями р. Прут являются коммунальные предприятия населенных пунктов Коломыя и Черновцы.

Научная новизна. Получила дальнейшее развитие методология оценки нагрузок на речной бассейн путем расчета индикаторов нагрузки, что позволяет разрабатывать и внедрять эффективные методы и средства управления экологической безопасностью водных экосистем.

Практическая значимость. Полученные результаты являются основой для адаптации европейских подходов к интегрированному управлению водными ресурсами и разработки мер по минимизации рисков от антропогенной деятельности в бассейне Прута. Работа нашла практическое внедрение на национальном уровне при разработке проекта Плана управления речным бассейном Прута в рамках международного проекта ЕС „Охрана окружающей среды международных речных бассейнов“ (EPIRB) и совершенствовании системы мониторинговых исследований вод на территории Карпатского национального природного парка.

Ключевые слова: экологическая безопасность, точечные и диффузные источники загрязнения, индикаторы нагрузки

Рекомендовано до публікації докт. техн. наук Я. О. Адаменком. Дата надходження рукопису 02.08.17. 